\title{
Throughout Cycles
}

\section{Welcome by the Editor-in-Chief}

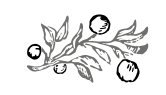

Journal of Economic Literature (JEL) codes: B20, N01

Keywords: economic policy, social policy, Hungary

We kindly recommend you the combined Hungarian edition 1-3 of Volume 14 of Polgári Szemle, our journal of social sciences. This periodical publishes studies in economics and social policy. The specialized journal is rated and proofread by the Hungarian Academy of Sciences. Courtesy of our sponsors, two issues are published in Hungarian and one in English every year, and from 2018, an issue will also be released in China.

The authors of our publications are high-ranking representatives of Hungarian academic life, public administration, the National Bank of Hungary and the State Audit Office, who publish their ideas, embedded in an international context and a historical perspective, in an endeavour to give an overview of the main economic and social developments related to the Hungarian State, re-organized after 2010, and to the evolving academic systems. Our scholarly authors also give glimpses of Hungarian history and portray various historical figures, the most recent academic books are reviewed, and even the fledgling attempts of and papers by young researchers are given room in the journal. According to our self-definition, Polgári Szemle is a social journal in the original sense of the term (including the areas of law, economics, social policy, polity, history and politics). In a more specific approach, this periodical tracks development in social sciences, serves as a cradle for new and novel academic achievements, and analyses the current global and national trends and events using scientific methods.

In the first Hungarian issue of 2018 (an English one was published in February 2018), I would like to recommend two papers for the reader's special consideration.

University professor Miklós Maróth, classical philologist and orientalist awarded the Hungarian Corvin Chain and the Széchenyi Prize, and a full member of the Hungarian Academy of Sciences, has published a paper about How to Preserve Europe's Christian Identity. At the end of the study built on the history of the related ideas and on extensive references, the author gives an inspiring answer to the question asked in the title:

Ad 1/ "In order to rescue Europe from the harmful effects of Islam, paradoxically, we should learn from Islam itself. First and foremost, we should learn to take our own religion seriously. Nowadays we can see that young people's view of the world is no 
longer shaped by their families or churches, but by American films and journals. That is where they find role models and that is what shapes their frames of mind. However, these sources are not authentic, and the worldview they convey is incompatible with our religious teachings, as they represent a utilitarian, nihilistic ideology grown on the basis of German historicism. With a few exceptions, the churches are not present in the production of films that have serious messages and are nevertheless entertaining."

Professor Maróth goes on in his argumentation as follows: ad 2/ "If we do not take our own religion and the culture built on Roman roots and based on this religion seriously, and fail to set up strong communities, Islam, characterized by a strong identity and sense of community, will overpower us. The closing up of Christian churches will continue, one after the other, while mosques will be simultaneously built, as we can see in various countries in Western Europe today."

As an additional reminder (ad 3/), he adds: "...dialogue with Islam should be avoided when it comes to religious matters. The reason is that Muslims are firmly convinced that only they have the truth and that we are fraudsters, they will never give up an inch. Following the laws of Islam, they unilaterally want to proselytize, and they despise and reject everything outside Islam. They will demand the adoption of their laws in our countries, and in the spirit of the prevailing ideology that is a corollary of German historicism, we will give way to it, as "everything is equally good, everything is merely an outcome of historical development'."

In Miklós Maróth's opinion, the way forward, or to paraphrase it in a more common way, our survival requires the following: "Efforts can, however, be made at cooperation with Islam to protect our commonly professed values... As explained by its leaders on several occasions, Islam cannot be globalized. Thus, Islam can be our most powerful ally against the threat of globalism. We should learn the power of community and the strength lying in solidarity from Islam."

In his paper, Dr Stephen Count of Bethlen, a count of time-honoured Transylvanian lineage (his father, the late Dr László Bethlen was an attorney, Member of Parliament and the Chairman of Transylvanian Cooperatives, and his mother was the late Countess Katalin Teleki of Szék), makes a comparison between the economic policies of the Bethlen Government after the Trianon Peace Treaty and of the Orbán Governments after 2010.

Based on Count Bethlen's qualifications in economics, philosophy and polity, his senior positions held in the German economy and banking, his currently active university professorships, several years spent in the United States, membership in Hungarian National Assembly as an MDF Party representative and his chairmanship of the Hungarian Pan-European Union, he concludes that "governance after the 2010 economic and financial policy change has been showing increasing similarity with the 1920s". The international financial expert, who returned to Hungary on the invitation of the late PM József Antall, outlines the fundamental concepts, means and achievements of his forefather, PM Bethlen's economic and financial policy, ${ }^{1}$ and makes efforts at highlighting the lessons that can be learnt today. He is looking for correlations between the past and current economic policy events. He concludes that 
Hungarian Prime Minister Count István Bethlen reached the summit of his more than decade-long governance in 1928. Ninety years later, it can be established that under the leadership of Dr Viktor Orbán, who considers the martyred Prime Minister as his role model, Hungary is on the right track towards the creation of a genuinely modern economic and financial policy rather than following an ossified, 250 years old, orthodox liberalism or neoliberalism that spectacularly failed during the 20072008 financial crisis.

I can also warmly recommend the writings by constitutional judge and professor of law Béla Pokol; by university reader Ferenc Somogyi, who organizes civil disputes at Lake Balaton; by professor of history, Gergely Egedy, who likens the reality of Brexit to a Greek mythological twist; by András Giday and by many others.

We hope that you will enjoy this publication just as the previous issues and will find useful information in it. Please do not hesitate to call the attention of your foreign colleagues to Polgári Szemle, which is dispatched to the shelves of major international universities and national libraries, especially the English and Chinese versions, copies of which are forwarded to diplomatic corps and to intellectual workshops in Hungary and across the borders.

Unfortunately, as an editor-in-chief of a scientific journal, I regularly have to say final farewell to our authors who pass away, acknowledge their lifetime achievements and place the flowers of grace on their intellectual graves.

First, we remember Széchenyi Prize awarded professor Pál Tomcsányi (1924-2018), who died on 22 February. With his writings he provided valuable input to our journal on numerous occasions, and rendered specific assistance to the academic rating of Polgári Szemle. Pál Tomcsányi was well-versed in such affairs, as his most important academic achievements were made exactly in the field of science management. In 1966 he elaborated the concepts related to researchers' knowledge management and his book on research methodology ran through several editions. Graduate and postgraduate students learnt from his textbooks for decades. His original, perhaps first, professional orientation was the continuous elaboration of the scientific methods in agricultural marketing. I will never forget his proposition I learnt for the mid-term examinations during my PhD course: as the farmers of Nagykốös carried fruit to the marketplace in nice wicker-baskets, the merchandise looked and sold better.

Pál Tomcsányi was a regular member of the Hungarian Academy of Sciences. He was the son of Vilmos Pál Tomcsányi (1880-1959), Minister of Justice in the Bethlen Government, and he was the nephew of lawyer and academician Móric Tomcsányi (1878-1951). His numerous papers published in Polgári Szemle called for reverence for science and emphasized the significance of education.

A final good-bye was also said to Zoltán József Tóth (29 January 1967 - 28 January 2018), an outstanding representative of the Doctrine of the Holy Crown and a law historian, who handed down his legacy to us in books he wrote and edited. His books include: Hungarian Public Law Traditions and National Consciousness from the End of the 19 th Century to Date. Szent István Társulat, Budapest, 2007; The Constitution of Our Survival. The Doctrine of the Holy Crown in the History and Public Law of Hungary. HUN-idea, 
Budapest, 2007; Life in the Spirit of the Holy Crown. A Society Built on Hungarian Values. Magyarok Világszövetsége, Budapest, 2011; Before the Storm - At Crossroads Két Hollós, Budapest, 2011; Prior to Denouement - On the Verge of Collapse Két Hollós, Budapest, 2014; He edited the following books: The Holy Crown of Hungary and the Doctrine of the Holy Crown at the Turn of the Millennium. Szent István Társulat, Budapest, 1999; Truth and History - A Collection of the Ideas of Tamás Molnár. Szent István Társulat, Budapest, 2000.

As an associate professor, Zoltán József Tóth taught thousands of students at the Pázmány Péter Catholic University, the National Public Service University and other higher education institutions. His memory will stay in the souls of his students and colleagues, in his books and in his papers frequently published in Polgári Szemle.

We will remember academician Pál Tomcsányi, professor of the Szent István University, and associate professor Zoltán József Tóth, former deputy minister of state, and the editorial board pays tribute to their work and achievement.

Dr Csaba Lentner, university professor

Editor-in-chief of Polgári Szemle

Awarded the Officer's Cross

of the Order of Merit of Hungary, on recommendation of the conservative government, on 20 August 2018

\section{Note}

1 An excellent and detailed summary of the economic and social policy achievements of the more than ten-year term of the Bethlen Government is given in a book entitled Count István Bethlen and the Hungarian Economy. An Economic Policy Study (published by the author, 1930, 192 p.). 